\title{
Editorial
}

\section{Food insecurity - not just about rural communities in Africa and Asia}

In June, the FAO reported that world hunger will reach a historic high this year, with over one billion people projected to go hungry every day ${ }^{(1)}$. Here is what Margaret Chan, Director-General of WHO, had to say in July ${ }^{(2)}$ : 'We are in a mess. The financial crisis hit the world like a sudden jolt, and it hit the world where it hurts the most: money. [...] All countries, rich and poor, north and south, are affected. But this is a crisis that will hurt the poor the hardest and the longest.... Globalization has not turned out to be the rising tide that lifts all boats. Instead, wealth has been created and spread in waves that lift the bigger boats but swamp or sink many smaller ones'.

This month we continue last month's theme. Food insecurity is often perceived as a public health crisis principally for impoverished rural communities in lowincome countries. This is a misperception. The crisis is most acute in Africa and Asia, but the urban poor are just as vulnerable, and food insecurity is an issue within and around cities all over the world.

\section{The crisis in cities}

A report by UN-HABITAT projects that two billion people will be urban slum-dwellers by the year 2030. People who live in slums, shanty towns, favelas, camps and on streets are especially hard hit by the current economic crisis ${ }^{(3)}$. For many impoverished urban families already living on the margin, the crisis means destitution and even starvation. City dwellers, whatever their available income, almost always rely on markets for food, including basic staples, which are usually transported long distances, often from other parts of the world, rather than being grown locally ${ }^{(4,5)}$.

In 2008, steep food price increases caused riots in over thirty countries throughout Africa, South Asia and elsewhere $^{(6-8)}$. Higher-income countries are also vulnerable. In the USA, the non-profit organisation Feeding America stated that all 160 of the food banks it surveyed have reported an increase in demand for food assistance ${ }^{(9)}$.

\section{Low incomes, expensive food}

Two characteristics of food insecurity in cities distinguish it from food insecurity in rural areas. First, while rural communities may still depend on subsistence farming with all its fragilities, food insecurity in cities is usually due not to lack of available food but to inadequate purchasing power ${ }^{(5)}$. The current global recession has reduced the employment opportunities and income of the urban poor $^{(10,11)}$. In the meantime, other economic forces have decreased food affordability. In the world food price crisis of 2008 , the combination of a spike in commodity prices, emerging economies' increased demand for food and the use of food resources to make biofuels, among other factors, led to steep price increases. The riots that resulted are easily explained. In the words of Arif Husain, a senior food security analyst at the World Food Programme: '[I]f you're hungry, you get angry quicker ${ }^{(6)}$.

\section{The issue of quality}

Second, whereas food insecurity has usually meant shortage of dietary energy, in cities all over the world it has now become as much about quality (malnutrition) as it is about quantity (undernutrition) ${ }^{(10)}$. Vast populations of food-insecure city dwellers worldwide are now vulnerable to obesity, diabetes and other chronic conditions. Again, in the words of Margaret Chan: 'Global trends, such as the industrialization of food production and the globalization of its marketing and distribution, help feed the world. But these trends have also contributed to a public health crisis. ... When money is tight, the first things that drop out of the diet are usually the healthy foods, like fruits, vegetables, and lean sources of protein, which are nearly always more expensive. Processed foods, rich in fats and sugar and low in essential nutrients, become the cheapest way to fill a hungry stomach. This is the type of diet linked to the rise of chronic diseases ${ }^{\text {,(2) }}$.

In cities, many of the most available and affordable foods are high-calorie junk. Nutrient-dense foods sold in shops such as fresh vegetables, fruits and fish are too expensive to be part of regular diets ${ }^{(10,12)}$. Making matters worse is that high-calorie junk - engineered by big manufacturers to encourage overeating ${ }^{(13)}$ and marketed as a defining and indispensable part of the good 'lifestyle' - may seem more desirable than nutrient-dense foods ${ }^{(14)}$.

\section{The big picture}

The first thing we as public health nutrition professionals can do, is to recognise and act on the fact that we are just 
as much a part of the public health community as we are of the nutrition community, with all this implies ${ }^{(15)}$. Dietary recommendations by themselves do not address social and economic inequities; there is little point in advising that families consume more fresh perishable foods when their livelihoods depend on growing crops for export, when they have no money, or when they know that fresh foods are unsafe to eat.

It stands to reason that strategies to address urban food insecurity should improve the urban poor's purchasing power, and increase the availability and affordability of nutritious foods. All schoolchildren - and their parents too - should also receive a basic education on their own vulnerability to marketing strategies of the food industry.

In its Comprehensive Framework for Action, the UN High Level Task Force on the Global Food Security Crisis urges more local food production, and sustainable urbanisation ${ }^{(4)}$. These certainly are big steps in the right direction. But along with this is an immediate need for political will, so that governments make sure such steps are taken. Such political will depends on our understanding the root causes of the food global food insecurity crisis and our commitment to take action, as professionals and as citizens.

\section{Agneta Yngve Barrie Margetts Roger Hughes Marilyn Tseng Editor-in-Chief and Deputy Editors Public Health Nutrition}

\section{References}

1. Food and Agriculture Organization of the United Nations (2009) 1.02 billion people hungry: one sixth of humanity undernourished - more than ever before. http:// www.fao.org/news/story/en/item/20568/icode/ (accessed June 2009).

2. Chan M (2009) Focus on health is the key to welfare of humanity. Address to the Economic and Social Council
2009 High-level Segment, Geneva, 6 July 2009. http:// www.who.int/dg/speeches/2009/health_focus_20090706 (accessed June 2009).

3. UN-HABITAT (2007) Slum Dwellers to double by 2030: Millennium Development Goal could fall short. http:// www.unhabitat.org/downloads/docs/4631_46759_GC\%2021\% 20Slum\%20dwellers\%20to\%20double.pdf (accessed August 2009).

4. Ki-moon B, Diouf J, Holmes J \& Nabarro D; High-Level Task Force on the Global Food Security Crisis (2008) Comprehensive Framework For Action. http://www.un. org/issues/food/taskforce/Documentation/CFA\%20Web.pdf (accessed August 2009).

5. Shapouri S, Rosen S, Meade B \& Gale F (2009) Food Security Assessment, 2008-09. USDA/ERS Outlook Report no. GFA-20. http://www.ers.usda.gov/Publications/ GFA20/ (accessed June 2009).

6. Lacey M (2008) Across globe, empty bellies bring rising anger. The New York Times, 18 April.

7. Baker P \& Dugger CW (2009) Obama enlists major powers to aid poor farmers with $\$ 15$ billion. The New York Times, 8 July.

8. Bradsher K (2008) A new, global oil quandary: costly fuel means costly calories. The New York Times, 19 January.

9. Feeding America (2009) Local Impact Study. http:// feedingamerica.org/newsroom/local-impact-study.aspx (accessed June 2009).

10. Drewnowski A \& Darmon N (2005) The economics of obesity: dietary energy density and energy cost. Am J Clin Nutr 82, Suppl. 1, 265S-273S.

11. Food and Agriculture Organization of the United Nations (2009) More people than ever are victims of hunger. Background document. http://www.fao.org/fileadmin/ user_upload/newsroom/docs/Press\%20release\%20june-en. pdf (accessed June 2009).

12. Darmon N, Briend A \& Drewnowski A (2004) Energydense diets are associated with lower diet costs: a community study of French adults. Public Health Nutr 7, 21-27.

13. Kessler D (2009) The End of Overeating: Controlling the Insatiable American Appetite. New York: Rodale Inc.

14. Raschke V \& Cheema B (2008) Colonisation, the New World Order, and the eradication of traditional food habits in East Africa: historical perspective on the nutrition transition. Public Health Nutr 11, 662-674.

15. World Federation of Public Health Associations (2009) The Istanbul Declaration. Health: the First Human Right. http:// www.wfpha.org/2009_Turkey/Istanbul\%20Declaration $\% 20$ and\%20annex\%20(3).pdf (accessed August 2009). 